\title{
Analysis on the Creative and Artistic Features of Ancient Poetry Art Songs in the First Half of 20th Century
}

\author{
Yu Xiang \\ Music and Dance Institute \\ Qujing Normal University \\ Qujing, Yunnan, China 655011
}

\begin{abstract}
Ancient poetry art song is an important category of Chinese art songs. Referring to the Western compositional concepts in techniques and selecting lyrics from Chinese ancient poems, ancient poetry art song is a mixing result of Chinese and Western culture. The first half of 20th century is a period when Chinese art songs emerged, developed and prospered with numerous composers creating fruitful ancient poetry art song. As for the artistic feature, the works of this period have not only the generality of the time but also the individuality of music and composer.
\end{abstract}

Keywords-the first half of 20th century; ancient poetry art song; creation; artistic feature

\section{INTRODUCTION}

Since the movement of school songs in early 20th century, the development of Chinese music has stepped into a new period. Composers began to adopt the compositional concepts of West such as the west mode in music technique, harmony, duplicate accent technique, multi-tone technique, etc. The musical form like tonality layout was attached attention. While keeping the national characteristic, the creation of songs began to be introduced the western art song concepts and learned their creative technique - trinity of piano accompaniment, music and poems. From the first half of 20th century especially around May 4 Movement, a group of excellent composers tried to compose art song by a way of combining Chinese and Western culture namely adopting western techniques in music and continuing to use ancient poems which had luxuriant historical and cultural sedimentation. Therefore, a group of splendid ancient poetry art song came into the world.

\section{A SUMmary OF ANCIENT POETRY ART SONGS IN THE FIRST HALF OF 20TH CENTURY}

\section{A. The Bud of Ancient Poetry Art Song}

Emerged from the singing movement in new-type school early in 1898, school songs were the buds of ancient poetry art song. Being westernized in its score, theories and techniques, school songs replaced the traditional Gongche notation with stave and numbered musical notation and imported the western music knowledge and techniques. Selecting music and then composing lyrics were the general creating method of school songs, while these outstanding composers like Li Shutong and Shen Xingong sometimes composed the lyrics and music themselves to create some works with an ancient poetry style. For instance, the Springtime Excursion, Farewell Song and Early Fall of Li Shutong, the Picking Lotus and Yellow River of Shen Xingong, etc.

\section{B. The Development and Prosperity of Ancient Poetry Art Songs}

With the vigorously launching of May-4 movement, various new culture and thoughts continuously came forth. In music, numerous music institutes like Shanghai National Music Institute, National Beiping Art School and State Conservatory of Music were emerged, so were the outstanding composers and excellent music works. Therefore, ancient poetry art songs took the course of a mature and prosperous development. The representatives of ancient poetry art song in this period were Xiao Youmei, Qing Zhu, Zhao Yuanren, Huang Zi, He Luting, Liu Xue'an, Jiang Dingxian, Chen Tianhe, Tan Xiaolin, Xi Xinghai, etc.

Xiao Youmei's works of ancient poetry art song: Xiao Youmei contributes a lot to the creation of art song with a total of over 100 art songs. He has published Collection of Music Today which had 21 songs and New Song Collection which had 25 songs. Asking, his representative work, marks the maturity of Chinese art song. The lyrics of most his art songs are written by Yi Weizhai. Although some lyrics are new poems, they still have the imprint of ancient poetry which are categorized into the ancient poetry art songs such as Whispers of Wild Goose Flying to South, Rosy Cloud Song, The Song for Spring Outing, etc.

Qing Zhu's works of ancient poetry art song: influenced by western music thoughts such as Classicism and Romanticism when he studied in Germany, Qing Zhu has been especially skilled in describing the delicate emotion in his works. Qing Zhu is the art song creating representative of adopting western advanced music thoughts to write music for ancient poetry with Chinese traditional culture. In the relation of lyric and music, Qing Zhu has his own take on the genre. He advocates that music is exactly music but not the dependency of poetry, 
and he even believes that rhyme is the tomb of music. His representative works are as follows: he composed music for $\mathrm{Su}$ Shi's poems East Flows the Mighty River and To the Tune of Nian Nu Jiao, I Live at The Source of The Yangtze River of $\mathrm{Li}$ Zhiyi's cognominal poem in Song dynasty, Eternal Love Red Flowering Branches of Feng Yanji in Southern Tang, and published songbooks - Melody Collection and Music Realm. Melody Collection has ten songs, among which six songs come from great poets in history, for example, Wuling Spring of Xin Qiji in Song dynasty, Memories of the South of Bai Juyi in Tang dynasty, Coming Home of He Zhizhang in Tang dynasty, Words for Counts of Wang Yan in Shu, Words for Soldiers of Liu Ji in Ming dynasty, and Longevity Girl of Feng Yanji; and four songs come from ancient novels and Ballads namely The Sun Scorching like Boiling Water from Water Margin, Yue Ballad from Fudoki, the ancient poem Everybody Says Good Fairy and the ancient ballad - Jirang Song.

Huang Zi's works of ancient poetry art song: influenced by the traditional Chinese culture, Huang $\mathrm{Zi}$ prefers ancient poetry especially Tang and Song poetry. His ancient poetry art song has a lofty style and strict rhythms. Having early studied in America, Huang $\mathrm{Zi}$ introduced the western compositional concepts and pays great attention to the combination of poetry and song. The ancient poetry art song of Huang $\mathrm{Zi}$ has a farreaching influence which affects the creation of his students like He Luting, Liu Xue'an, Chen Tianhe, Jiang Dingxian and so on, and impacts the creation of Chinese songs in 20th century as well. The representative works of his ancient poetry art songs are as follows: Nan Xiang Zi which is composed for the cognominal poem of a poet in Song dynasty; Flower in the Mist for the cognominal poem of Bai Juyi, famous poet in Tang dynasty; Crimson Lips ·Deng Lou Fu for the cognominal poem of Wang Zhuo in Song dynasty; Doppler Operator for the cognominal poem of Su Shi in Song dynasty. Although his other works adopt the contemporary poetry, the poetry also has marks of ancient poetry, which is included into the category of ancient poetry art song such as Yearning Song, Plum Blossoms in the Snow, etc.

The ancient poetry art songs of Chen Tianhe, Liu Xue'an and Jiang Dingxian: Chen Tianhe, Liu Xue'an and Jiang Dingxian once apprenticed Huang $\mathrm{Zi}$. The works of Chen Tianhe inherits the essence of Huang Zi's works. Thinking much of works' national characteristic, he composes art songs which have a simple style and compact structure, and integrate western techniques with national elements. His representative works of ancient poetry art song are as follows: Qing Pingle. Where Has The Spring Gone composed for the cognominal poem of Huang Tingjian in Song dynasty, Mulberry Song for an ancient poem, Who Sit Alone Aside Window composed for the cognominal poem of Xiang Gao in Song dynasty, La Strada - Playing Guzheng composed for the cognominal poem of Ouyang Xiu in Song dynasty, Buddha's Boogie. Personal Life and Death Are as Light as Swallows composed for the cognominal poem of Yan Jidao in Song dynasty, To Moor at Night at the Maple Bridge composed for the cognominal poem of Zhang Ji in Tang dynasty, Jiang Cheng Zi . West Willow Alley Spring Soft composed for the cognominal poem of Qin Guan in Song dynasty, other ancient poetry art songs like Wang Yue which are included in the songbooks of Reminiscence Collection, Vocal Creation Collection, etc. Jiang Dingxian is a master of composing accompaniment for ballads. Creating ancient poetry art song as well, he composes works which have the dramatic melody with skilled techniques and expressive accompaniment. The representative work of his ancient poetry art song is the cognominal vocal music composed for ancient poem Cotton. Although Quiet Mood is composed for new poem written by the contemporary Liao $\mathrm{Fu}$, it also has the typical features of ancient poetry art song. Liu Xue'an's Red Bean Song (its lyric's author is Cao Xueqin in Qing dynasty) and Lotus Song are important works of this period.

The ancient poetry art songs of Tan Xiaolin and Jiang Wen: having studied in America in his early days, Tan Xiaolin is very familiar with western compositional techniques especially the compositional concepts of his professor - Hindemith; for once apprenticing to Huang $\mathrm{Zi}$, he inherits Huang Zi's creating style namely preserving national traits; and he himself has a strong interest in Chinese traditional culture and folk ballads; all the above rich learning experience, advanced and solid compositional foundation, as well as his deep-seated historical and national cultural background serve for his uniqueness in creating music. Ancient poetry art song is one significant part of Tan's creation, the representative works of which are as follows: $G u$ Lang $J i$ composed for the cognominal poem of Zhu Xizhen in Song dynasty, composing music for Since You Left Me of Zhang Jiuling in Song dynasty, Song of Righteousness of Wen Tianxiang in Song dynasty and Spring Wind and Rain of Zhu Xizhen in Song dynast, etc. Jiang Wen is described as a prolific composer rarely seen in Chinese music history who has a complex and bumpy life experience, owning a distinct and tenacious artistic individuality as well as full of boldness and innovation. [2] Deeply influenced by Chinese traditional music culture too, Jiang Wen values the national elements in music. He is good at creating with western compositional methods meanwhile takes Chinese traditional culture as the mainline of music. The ancient poetry art songs he created are as follows: music composing for Hearing a Bamboo Flute on a Special Night in Luoyang of Li Bai and Riverside Village Scene of Sikong Shu in Tang dynasty, as well as Prelude to Water Melody of Su Shi, Spring Scene of Ouyang Xiu and Mourning Spring of Wang Anshi in Song dynasty, etc.

The ancient poetry art songs of He Luting and Xi Xinghai: in art song creation, He Luting is adept in integrating historical materials with songs. By tightly combining revolutionary practices, he endows his creation with a sense of time mission like his representative works - On Jialing River. As apprenticing to the compositional concepts of Huang $\mathrm{Zi}$ in techniques, He Luting excels in creating ancient poetry art song which is the product of western and Chinese culture. His masterpieces of this genre are the music composed for Pusaman and Night Thoughts of Li Bai in Tang dynasty. Being the musician of the masses, $\mathrm{Xi}$ Xinghai dabbles in various themes such as the magnificent vocal and instrumental music as well as short and delicate art songs. The art song creations of Xi Xinghai illustrate not only his unique aesthetic but his subtle creating techniques. There are totally over twenty pieces 
of Xi's ancient poetry art songs, and the representative ones are shown in the following: the Songbook of Ten Ancient Poems finished in 1944 which includes music composing for Butterflies Lingering over Flowers and The Tune of Bu Suan Zi of Su Shi in Song dynasty, Zhu Zhi Ci for Yang Lianfu in Yuan dynasty and Liu Yuxi in Tang dynasty, To a Faithless Husband of Zhuo Wenjun in Han dynasty, Tempest of Book of Odes - Zheng Feng, Long Tou Song and Yin Ma Changcheng Ku Xing of Yue Fu poems of Han Dynasty, On and On, Going On and On - one of 19 Poems of Eastern Han Dynasty, Mourning — an ancient poem. Besides, Yi Qin E composing for the poem of Li Bai in Tang dynasty, The Crows Crying at Night composing for the poem of $\mathrm{Li} \mathrm{Yu}$ - the Southern Tang Emperor, and Parting Feelings composing for Lu Benzhong's poetry in Song dynasty are Xi's representative works of ancient poetry art song.

Besides the above composers, other people who engaged in researching the ancient poetry art song in the first half of 20th century are as follows: Ying Shangneng who composed music for Wu Yi in Book of Odes - Qin Feng, Zhang Xiaohu who composed music for Shengshengman of Li Qingzhao in Song dynasty, Huang Yongxi who composed for Yangguansandie of Wang Wei in Tang dynasty, etc. Ma Sicong contributed a lot to ancient poetry art song. Besides his music composing for The Setting Sun and Untitled - It's So Hard to Say Goodbye of Li Shangyin in Tang dynasty, he also composed for six poems of Li Bai namely Hard Is the Road of the World I and II, Border Mountain Moon, Moon Mountain, Invitation To Win and Eternal Love. The songbook - The Seven Ancient Poems was also created by him.

\section{The ARtistic FeAtures of AnCIENT PoEtry ART SONG IN THE FIRST HALF OF 20TH CENTURY}

\section{A. Introduction of Novel Compositional Techniques}

In music forms, composers not rigidly adhere to single structure. Based on the specific music and lyrics, they arrange the corresponding structures. Some of them are totally based on lyrics in arranging structures, which is the short single paragraph structure like Flower in the Mist. Another single paragraph structure is usually seen in creating ancient poetry art song of this period namely combining the creating methods of traditional poems with the qi-cheng-zhuan-he structure like Doppler Operator of Huang $\mathrm{Zi}$. Binary form and ternary form are more common in creating ancient poetry art song. For instance, in I Live at the Source of the Yangtze River, the composer used simple lyric and music to express his longing for faithful love. It consists of the first part with a prelude of four sections and other sixteen sections namely "At the top end of Yangtze I reside, at its bottom end you well abide, longing all day long but with no meeting both of us drink its water for living" as well as the second part with forty-eight sections which is repeated twice in the form of polyphony. The Spring Yearning and Homesickness of Huang Zi, Doppler Operator of Xi Xinghai and Red Bean Song of Liu Xue'an are classic examples of binary form. While East Flows the Mighty River is the typical ternary Form in ancient poetry art song.

The arrangement of mode and tonality and application of harmony in creating ancient poetry art song by composers in this period have reached to a supreme degree. Due to the background of their overseas studying in Europe, America and Japan, the composers in this period knew well about western compositional techniques and dared to try and apply them in creating art songs. The ancient poetry art songs created by Qing Zhu have subversively changed Chinese traditional music structures. By applying harmony, subject-development, polyphony and music form to creation, Qing Zhu has created works with obvious art song style of Germany and Austria. For instance, in the accompaniment of I Live at The Source of The Yangtze River, Qing Zhu has applied the European polyphony thought to design. Qing Zhu put forward a slogan in creating music namely establishing nationalized new music. The ancient poetry art songs created y him are elegant, craftsmanskilled and well-bedded. Besides this, he also deepened his research in tonality and harmony. By taking tonality as a tool for expression, he formed complicated tonality relations in his songs. For example, in Spring Yearning, series of transitions occur like F Gong - F Yu - E Gong - C Yu - F Gong. [3] When Huang $\mathrm{Zi}$ created art songs, the national characteristic was embodied. For example, in Spring Yearning, pentatonic scale was used, so were European music techniques like major-minor mode, diationic scale and so on. Moreover, the compositional methods like prelude, interlude and end referred to Schumann - the king of art song creation in Romantic period. The disciples of Huang $\mathrm{Zi}$ such as He Luting, Liu Xue'an, Jiang Dingxian, Chen Tianhe all are masters of art song creation. With the aid of rich harmony, elegant melody, proper rhythm and tone, the artistic conception and connotation of art songs are manifested incisively and vividly. $\mathrm{Xi}$ Xinghai lays emphasis on the rhythm combination of music and ancient poems in creating ancient poetry art song, while in music techniques, he draws into techniques like imitation, sequence and so on besides using pentatonic mode of traditional music.

The ancient poetry art songs of Tan Xiaolin are characterized by their distinctive themes, rich harmonic language, clear tonality arrangement, and more importantly, he fuses such principles as harmonic and tonality structure of the music system of Paul Hindemith into art song creation, while reserves the features of national music in melody. [4]

\section{B. The Reservation of National Features}

The most distinctive national feature in creating ancient poetry art song in the first half of 20th century is no better than the selection of lyrics. The art songs have delicate, elegant and beautiful aesthetic feature, which requires lyrics to be equipped with stronger literariness and artistry. [5] Having this feature, Chinese ancient poetry thus is valued by composers and leads to a large number of high-quality music. The lyric selection of ancient poetry art song has a long span from the first poetry collection - The Book of Songs to Tang and Song dynasty with prosperous poetry and culture and then to Yuan, Ming and Qing dynasties. The works of all ages which embody the essence of Chinese culture and national features are valued by composers.

The application of national folk tone is one form of ancient poetry art song reserving national features. By absorbing nutrients from folk tonality and ballads when using western 
compositional techniques, composers strengthen the exploration of Chinese music characteristics. The typical example of ancient poetry art song in 20th century which reserved national features is that composers reserve pentatonic scale and pentatonic mode when referring to western mode.

A lot of composers in creating ancient poetry art song used western techniques and fused the elements of Chinese folk music to possess the aesthetic of Chinese national culture. For instance, in Shengshengman, the composer, Zhang Xiaohu made its melody sounding like the national chanting; in East Flows the Mighty River of Qing Zhu, the characteristics of Kun Opera can be seen clearly. Huang Zi once said that, "the music of China must be created by the composers who have the soul of the Chinese nation and meanwhile master the Western music technique. What we should do now is to learn good western music methods so as to apply them to researching and arranging Chinese old music and folk ballads. If so, the national music will be generated without too many difficulties." [6]

\section{REFERENCES}

[1] Li Xi'an. Chinese Tone and Han Melody [J]. Music of China, 2009(2):2221230.

[2] Wang Yuhe. Approaching to the National Culture Tradition Discussion on the Changing of Jiang Wen's Music Creating Style [J]. People's Music, 2000 (11) : 11-16.

[3] Wang Dayan. Introduction to Art Songs [M]. Shanghai: Shanghai Music Publishing House, 2009(2):2221230.

[4] Chen Yan. The Nationality of Chinese Art Songs in the Early Twentieth Century [J]. Art Education, 2007(9):68.

[5] Wang Yuhe. Chinese New Music in the Integration of Chinese and Western Music in the First Half of This Century [J]. Journal of the Central Conservatory of Music, 1995(3). 